\title{
Isolation and identification of seed borne mycoflora associated with popular rice cultivars in North East India
}

\author{
Yashi Umbrey, Mudidana Divya, Tanusree Das, Srikanta Das and Sunita Mahapatra*
}

Bidhan Chandra Krishi Viswavidyalaya, Mohanpur (W.B.)

\section{Article history:}

Received: 06 July, 2021

Revised: 22 July, 2021

Accepted: 03 Aug., 2021

\section{Citation:}

Umbrey Y, M Divya, T Das, S Das and S Mahapatra. 2021. Isolation and identification of seed borne mycoflora associated with popular rice cultivars in North East India. Journal of Cereal Research 13 (Spl-1): 43-50. http://doi.org/10.25174/2582$\underline{2675 / 2021 / 112852}$

\section{*Corresponding author:}

E-mail: sunita.mahapatra071@gmail.com

(C) Society for Advancement of Wheat and Barley Research

\begin{abstract}
A total of 32 seed samples collected from 11 locations were tested for associated seed borne mycoflora by using blotter method and Agar plate method. In blotter method, eight mycoflora were identified based on spore morphology namely, Alternaria alternata, Aspergillus flavus, Aspergillus niger, Curvularia lunata, Fusarium sp., Bipolaris oryzae, Penicillium sp. and Trichoconis padwickii. Most frequently occurring fungi genera were Bipolaris $(25.76 \%)$, followed by Fusarium (20.92\%) and least in case of Penicillium (3.33\%). While in agar plate (PDA), maximum of 10 seed mycoflora like A. alternata, A. flavus, A. niger, C. lunata, Fusarium sp., Bipolaris sp., Nigrospora sp., Pencillium sp., T. padwickii and Trichoderma sp. were observed. Maximum percent occurrence was observed in genus Fusarium (22.67\%), Curvularia (20.06\%) and least in Nigrospora $(0.15 \%)$ and Trichoconis $(0.15 \%)$ respectively. Agar plate method showed maximum number of mycoflora on seeds than blotter method. However, it was observed that Bipolaris was predominant in blotter method and Fusarium in agar plate method.
\end{abstract}

Keywords: Agar plate method, blotter method, seed health, seed mycoflora

\section{Introduction}

Rice (Oryza sativa L.) is one of the staple food grain in Asian sub-continent and serves a billion population. In India, West Bengal, Uttar Pradesh, Madhya Pradesh, Punjab, Orissa and Bihar are the major rice producing states. In North east part of India, it is one of the primary diets being consumed daily and is a major source of livelihood for people dependent on rice cultivation. In this zone Rice crop is grown in varied agro-climatic conditions such as, in lower Gangetic plains (parts of West Bengal) and in Eastern Himalayan region (Meghalaya, Tripura and Arunachal Pradesh). But one of the major constrains in rice production is diseases caused by bacteria, fungi, viruses and nematodes; and are responsible for major economic losses in India (Mew and Gonzales, 2003). As such rice, is known to be affected by as many as a total of 153 seedborne pathogens among which $18 \%$ are of quarantine importance, $65 \%$ are native pathogen and $17 \%$ are storage pathogens (Naveenkumar, 2017) in India. Agrawal (1999) reported more than 50 fungal pathogens to be seed-borne in rice. The mycoflora associated with seeds causes various harmful effects in seeds are; loss of germination capacity, reduced seedling vigor, seed discoloration, decay, increase in fatty acids and utilization of carbohydrates for the synthesis of protein and toxin production etc. (Oh, 2007; Nguefack, 2008; Uma and Wesely, 2013; Mannaa and Kim, 2016). They not only reduce the quality of seed but also transmitted from one season to other and may provoke the introduction of new pathogens in a virgin 
area, causing quantitative and qualitative crop losses and permanent contamination of the soil (Ora et al., 2011).

Several fungal pathogens have been isolated from rice grains and have been reported to be responsible for a number of diseases from the nursery to the field (Ibiam et al., 2006). Therefore, using a good quality seed and performing seed health test to detect the presence of seed borne fungi becomes paramount to manage the diseases for healthy crop establishment. Considerable work has been done on seed health and detection of seed borne pathogens in rice seeds from different geographical region of the country (Sharma and Chahal, 1996; Gopalakrishnan and Valluvaparidasan, 2009; Gopalakrishnan et al., 2010; Archana and Prakash, 2013; Sharma and Kapoor, 2016; Singh et al., 2018). But, the information on seed health of rice varieties from different diverse geographical location of this region in particular the north east hilly region is scanty. The extent of discolouration varying with season, locality and variety was reported by Roy (1983), Mian and Fakir (1989) and Sunder et al. (1989). This might be due to variation of the weather conditions of agroclimatic zones, especially during harvesting period (Sharma and Kapoor, 2016; Das et al., 2016). Keeping in view the potential threat it may cause to the only staple food grain crop grown in the region, present study was taken up to determine the prevalence and extent of different seed borne mycoflora associated with different popular rice varieties originating from diverse geographical location.

\section{Materials and Method}

\subsection{Collection of samples}

Thirty-two rice seed samples were collected from 11 different locations i.e., Chakdaha, Jaguli, Gayespur, Kalyani, Hooghly, Purba Medinipur, Rampurhat, Uttar Dinajpur from West Bengal, Umiam (Meghalaya), Sabroom (Tripura) and Anini (Arunachal Pradesh) of North East India (Table 1 and Fig. 1). Seed samples were brought to laboratory in a plastic bag and kept at $4^{\circ} \mathrm{C}$ until further study. All the seeds samples were subjected to seed health testing following standard blotter method (Don, 2006) and agar plate method.

Table 1. Detailed information of seed samples collected from different locations of North East India

\begin{tabular}{|c|c|c|c|c|c|}
\hline Sl. No. & Varieties & Designation & Location/GPS Coordinate & District/ State & Source \\
\hline 1 & IET 4786 & $\mathrm{CDH} 1$ & CHAKDAHA (CDH) & \multirow{2}{*}{ Nadia, West Bengal } & \multirow{2}{*}{$\begin{array}{l}\text { Institutional } \\
\text { farm }\end{array}$} \\
\hline 2 & MTU 7029 & CDH 2 & $23.08^{\circ} \mathrm{N} 88.52^{\circ} \mathrm{E}$ & & \\
\hline 3 & Shatabdi & JGL 1 & JAGULI (JGL) & \multirow{2}{*}{ Nadia, West Bengal } & \multirow{2}{*}{$\begin{array}{l}\text { Institutional } \\
\text { farm }\end{array}$} \\
\hline 4 & Swarna & JGL 2 & $23.09^{\circ} \mathrm{N} 88.55^{\circ} \mathrm{E}$ & & \\
\hline 5 & Debgiri & GYP 1 & \multirow{4}{*}{$\begin{array}{c}\text { GAYESPUR }(\mathrm{GYP}) \\
22.98^{\circ} \mathrm{N} 88.48^{\circ} \mathrm{E}\end{array}$} & \multirow{3}{*}{ Nadia, West Bengal } & \multirow{3}{*}{ KVK farm } \\
\hline 6 & Maharaj & GYP 2 & & & \\
\hline 7 & Shatabdi & GYP 3 & & & \\
\hline 8 & Gobindobhog & HGY 1 & & \multirow{4}{*}{ Nadia, West Bengal } & \multirow{4}{*}{ KVK farm } \\
\hline 9 & Pratikshya & HGY 2 & \multirow{3}{*}{$\begin{array}{l}\text { HOOGLY HGY } \\
22.90^{\circ} \mathrm{N} 88.39^{\circ} \mathrm{E}\end{array}$} & & \\
\hline 10 & Swarna Masuri & HGY 3 & & & \\
\hline 11 & Swarna Sub & HGY 4 & & & \\
\hline 12 & Shatabdi & KYI-AB 1 & KALYANI AB KYI-AB & \multirow{5}{*}{ Nadia, West Bengal } & \multirow{6}{*}{$\begin{array}{l}\text { Institutional } \\
\text { farm }\end{array}$} \\
\hline 13 & Swarna & KYI-AB 2 & $22^{\circ} 58^{\prime} 30^{\prime \prime} \mathrm{N} 88^{\circ} 26^{\prime} 04^{\prime \prime} \mathrm{E}$ & & \\
\hline 14 & Gobindobhog & KYI-C 1 & \multirow{4}{*}{$\begin{array}{c}\text { KALYANI- C KYI-C } \\
22^{\circ} 58^{\prime} 30^{\prime} \text { N } 88^{\circ} 266^{\prime} 4^{\prime} \mathrm{E}\end{array}$} & & \\
\hline 15 & Harina Khori & KYI-C 2 & & & \\
\hline 16 & Radhuni Pagol & KYI-C 3 & & & \\
\hline 17 & Geetanjali & MDN 1 & & \multirow{4}{*}{$\begin{array}{l}\text { Purba Medinipur, } \\
\text { West Bengal }\end{array}$} & \\
\hline 18 & Kala Dhan & MDN 2 & Medinipur MDN & & \multirow{3}{*}{$\begin{array}{l}\text { Farmers saved } \\
\text { seed }\end{array}$} \\
\hline 19 & Paloi Dhan & MDN 3 & $22.424^{\circ} \mathrm{N} 87.319^{\circ} \mathrm{E}$ & & \\
\hline 20 & Sabita & MDN 4 & & & \\
\hline 21 & Swarna & RPH 1 & $\begin{array}{c}\text { Rampurhat }(\mathrm{RPH}) \\
24.17^{\circ} \mathrm{N} 87.78^{\circ} \mathrm{E}\end{array}$ & Birbhum, West Bengal & $\begin{array}{c}\text { Farmers saved } \\
\text { seed }\end{array}$ \\
\hline 22 & Hira & UDP 1 & \multirow{3}{*}{$\begin{array}{c}\text { Raiganj } \\
25^{\circ} 37^{\prime} \mathrm{N} 88^{\circ} 07^{\prime} \mathrm{E}\end{array}$} & \multirow{3}{*}{$\begin{array}{l}\text { Uttar Dinajpur, } \\
\text { West Bengal }\end{array}$} & \multirow{3}{*}{$\begin{array}{l}\text { Farmer's saved } \\
\text { seed }\end{array}$} \\
\hline 23 & Swarna & UDP 2 & & & \\
\hline 24 & IET 4094 & UDP 3 & & & \\
\hline
\end{tabular}


Seed borne mycoflora with popular rice cultivars

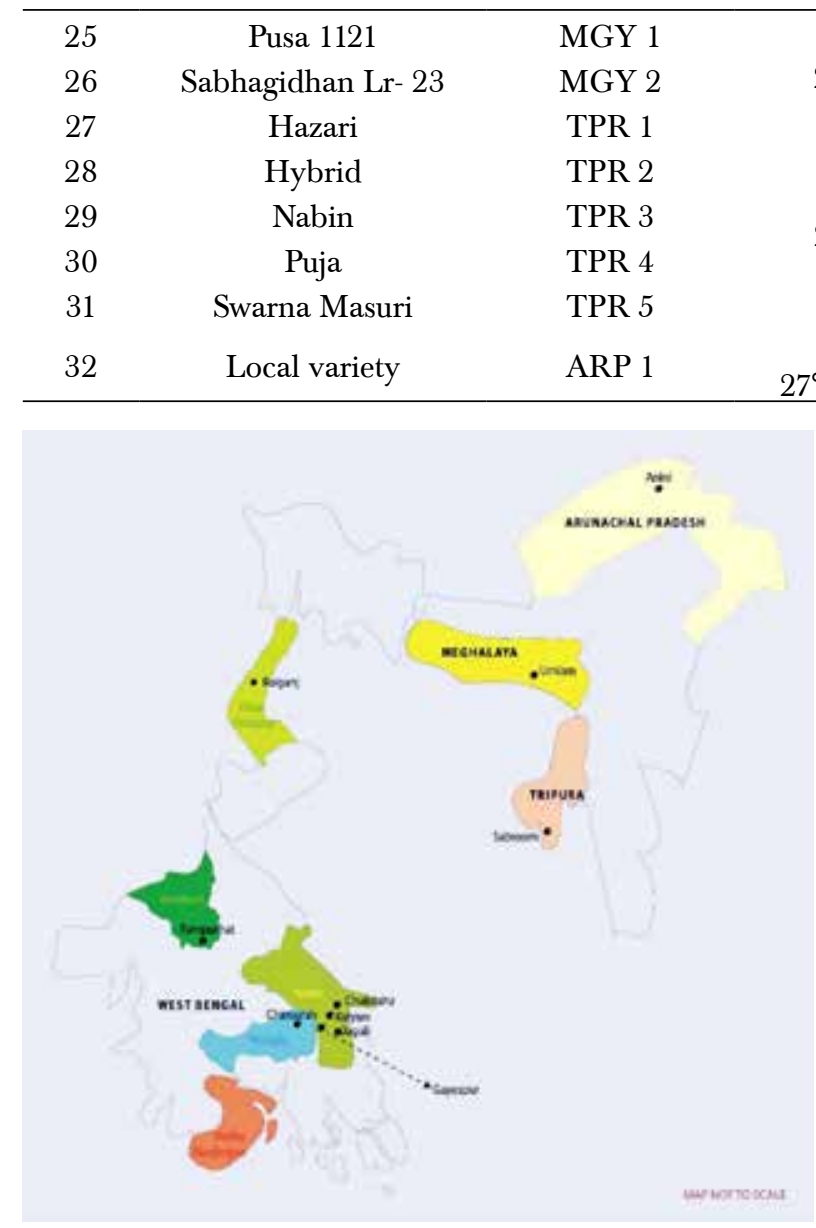

Fig. 1. Map indicating the rice seed sample collection locations

\subsection{Blotter Method}

Two hundred seeds were randomly selected from each sample and placed on three layers of moisten sterilized blotter paper at the rate of 25 seeds per Petri plate $(90$ mm diameter) using method developed by (Don, 2006). The seeds were surface disinfected with $1 \%$ sodium hypochlorite solution for $2 \mathrm{~min}$. followed by rinsing twice with sterilized distilled water and air dried prior to plating onto moistened blotting paper. Seed were placed in 1:8:16 fashion from the center to periphery and incubated at $25 \pm 1{ }^{\circ} \mathrm{C}$ for 7 days under $12 \mathrm{~h}$ alternating cycles of light and darkness. Incubated seeds were examined visually under stereo binocular microscope for the associated mycoflora. Identification was done based on their morphological character and microscopic examination of spores under zoomstar-v stereomicroscope (Barnett and Hunter, 1991; Mathur and Kongsdal, 2003; Mew and Gonzales, 2003). The percent incidence of the seed mycoflora was recorded in each sample.

\begin{tabular}{|c|c|}
\hline $\begin{array}{l}\text { Umiam } \\
.57^{\circ} \mathrm{N} 91.88^{\circ} \mathrm{E}\end{array}$ & Meghalaya MGY \\
\hline
\end{tabular}

Sabroom

Anini 759'0”N 9440’0'"E $23.00^{\circ} \mathrm{N} 91.73^{\circ} \mathrm{E}$

\subsection{Agar plate method}

Surface sterilized seeds were placed at ten seeds per Petri plate containing $20 \mathrm{ml}$ of PDA and incubated for 7 days as described in standard blotter method. The fungi growing out from the seeds were examined based on the colony appearance and identification of spore was done as described under blotter method. The laboratory experiment was conducted following completely Randomized Design (CRD) with four replications each.

\section{Results and Discussion}

In blotter method, from 32 seed samples collected from different locations of West Bengal, Meghalaya, Tripura and Arunachal Pradesh, eight seed borne mycoflora were observed like Alternaria alternata (0-30.25\%), Aspergillus flavus (0-37.50\%), Aspergillus niger (0-12.50\%), Curvularia lunata (6.63-31.25\%), Fusarium sp. (0-33.41\%) Bipolaris oryzae (0-37.75\%), Penicillium sp. (0-37.50\%) and Trichoconis padwickii (0-25.50\%) (Table 2). Also, fungal manifestation over the seed samples was visually examined under stereo binocular microscope and their fungal spore morphology showed different microscopic structure (Fig. 2 and Fig. 3).

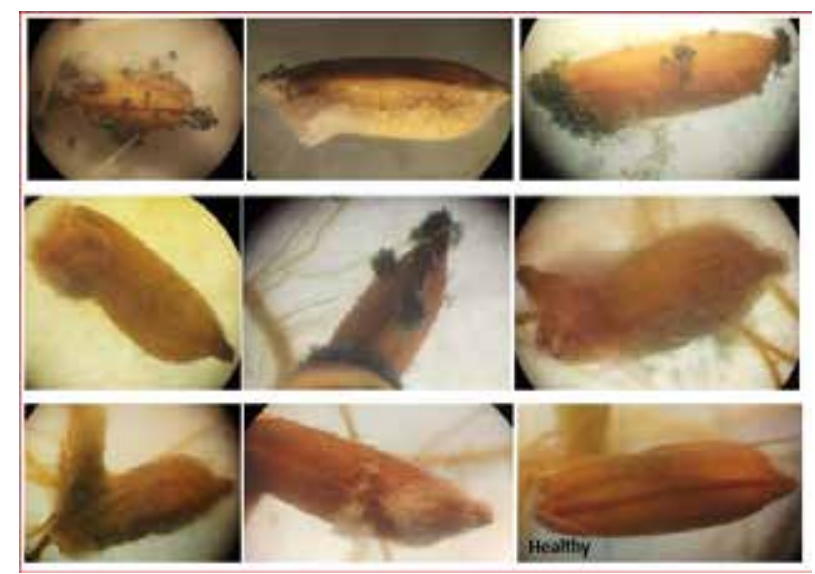

Fig. 2. Visual manifestation of seed associated mycoflora with rice seed along with an apparent healthy seed 


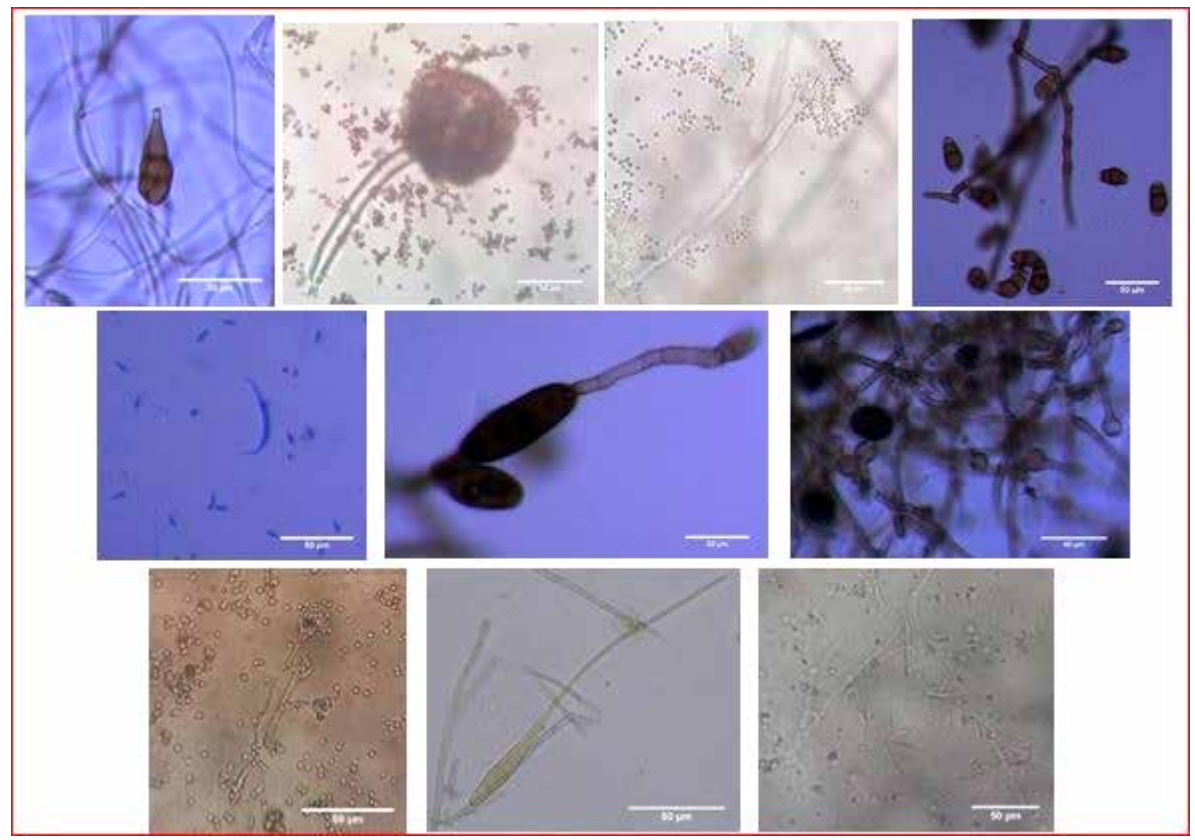

Fig. 3. Microscopic view of Seed borne mycoflora associated with Rice from top left to bottom right namely Alternaria alternata, Aspergillus niger, Aspergillus flavus, Curvularia lunata, Fusarium sp., Bipolaris sp., Nigrospora sp., Penicillium sp., Trichoconis padwickii, and Trichoderma sp.

Significant difference was observed with respect to associated seed mycoflora. Maximum per cent infection of A. alternata was seen on sample TRP-2 (30.25\%) followed by HGY $1(25.25 \%)$ and no infection was observed in samples MGY 1, HGY 3, MDN 2, and MDN 3. Sample MGY $1(37.50 \%)$ had maximum A. flavus infection followed by MDN $2(29.17 \%)$ and no infection in case of GYP 1, GYP 2, HGY2, HGY 4 and least 2.78\% in JGL 1. None of the samples were free from Curvularia infection, sample KYI-C 2 (33.58\%) and MGY 1 (6.63\%) showed highest and least percent infection, respectively. Fungi Fusarium and Bipolaris were found to be associated with varying percent in most of the samples tested with an exception for the sample MGY 1. Most of the sample did not show Penicillium and T. padwickii infection. Overall, irrespective of samples tested Bipolaris (25.76\%) was found to be the most predominant which is followed by Fusarium (20.92\%) and Curvularia (19.15\%). Similar, finding was also reported by many researchers. Mian and Fakir (1989) reported most predominant fungi in order of prevalence to be Helminthosporium oryzae, C. lunata, Cladosporium cladosporioides, Aspergillus spp. and T. padwickii. Ora et al. (2011) reported that among the 12 identified seed borne pathogens, Xanthomonas spp., Rhizopus stolonifer, Aspergillus sp., B. oryzae and $F$. moniliforme were pre-dominant on all tested hybrid rice varieties. Habib et al. (2012) also reported $B$. oryzae to be dominant fungal pathogen in seeds.

In agar method, ten seed associated mycoflora was observed A. alternata (0-9.76\%), A. flavus (0-20\%), A.niger (0-26.79\%), C. lunata (6.67-40.27\%), Fusarium sp. (0-45\%), Bipolaris sp. (0-8.47\%), Nigrospora sp. (0-4.76\%), Penicillium sp. (0-15.87\%), T. padwickii (0-4.76\%) and Trichoderma sp. (0-4.76\%). Their fungal spore morphology was examined under zoomstar-v stereomicroscope which showed different structure (Fig. 3). In this test also significant variation with respect to associated seed mycoflora was observed. C. lunata infection was observed in all the samples tested with maximum percent recorded in sample MDN 2 (40.27\%), followed by KYI-AB1 (34.72\%) and least in sample MDN 3 (6.67\%). Fusarium sp. infection was observed maximum in sample UDP $2(45 \%)$ followed by HGY 2 (40.34\%) and KYI-C 2 (39.44\%) while no infection was recorded in sample MGY $1(0 \%)$ and least in sample TRP 2 (8.33\%). Unlike blotter method Bipolaris infection was not predominant in agar method and only few samples were found to be associated with it. Fungi Nigrospora, Trichoconis and Trichoderma sp. were found in few samples of HGY 3 (4.76\%), TRP $2(4.76 \%)$ and CDH 1 (4.76\%), GYP $1(3.70 \%)$ respectively. Irrespective of all samples tested maximum percent infection was found to be of Fusarium sp. (22.67\%) followed by Curvularia (20.06\%) 


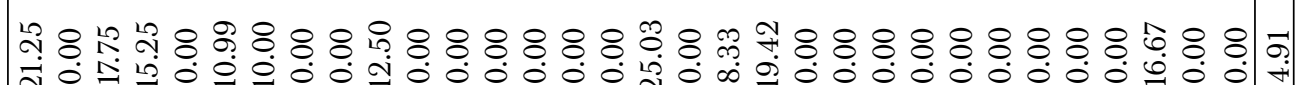

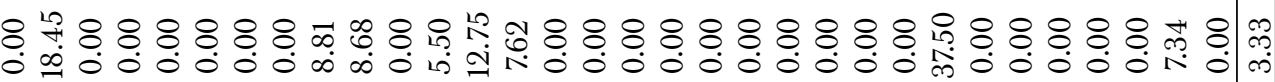

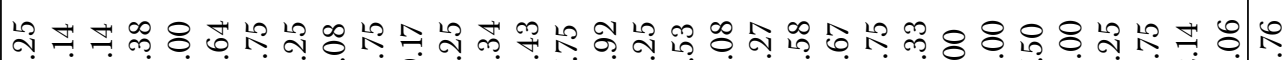
ฟ

웅 \& 8 .

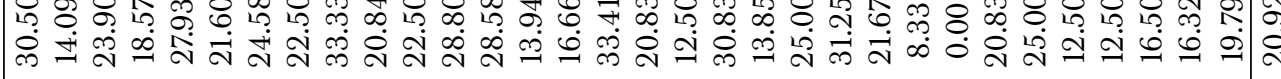

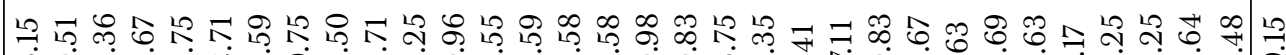

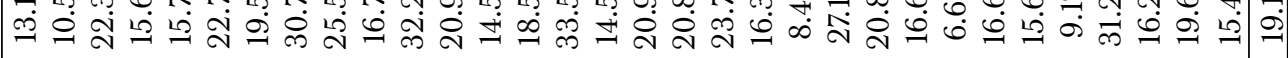

m

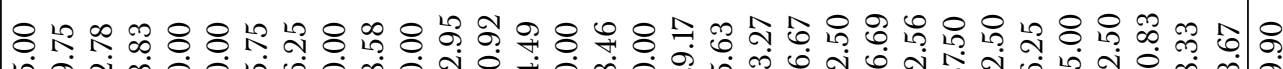

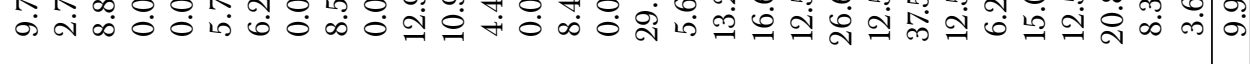

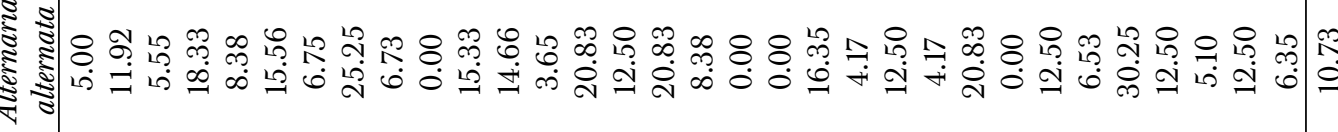




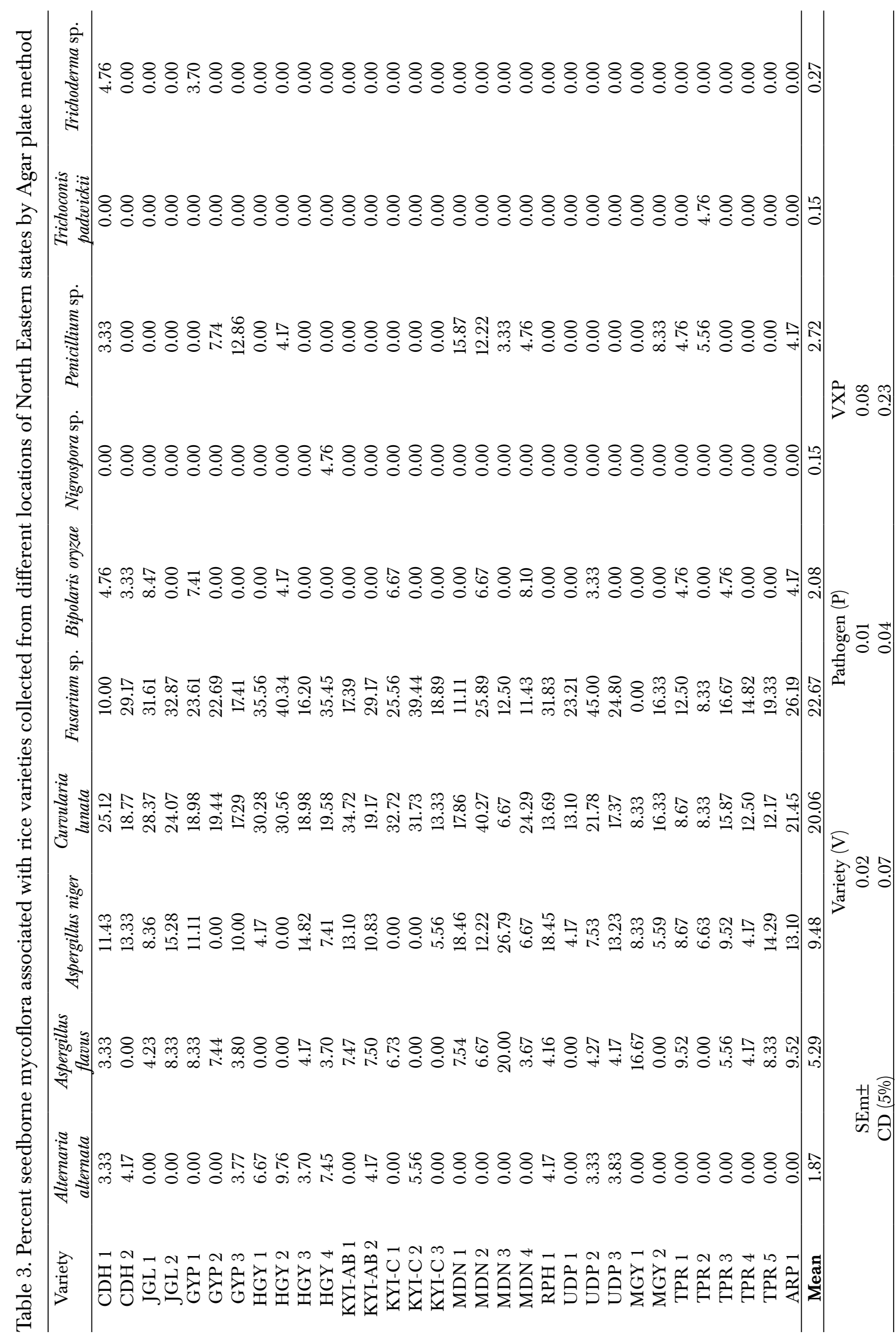


and least of Nigrospora sp. (0.15\%) and T. padwaki (0.15\%). Several researchers who have worked on seed heath test have also recorded similar findings. Similarly, Sharma et al. (1987) detected 10 fungal species from the rice seeds where they found F. moniliforme (Gibberella fujikuroi), C. lunata (Cochliobolus lunata), A. flavus to be most common. Ibiam et al. (2008) also reported F. moniliforme to be the most prevalent among the all the isolated fungi from rice seed in storage and field condition. Butt et al. (2011) isolated 12 seed borne pathogens among them Xanthomonas spp., $R$. stolonifer, Aspergillus sp., B. oryzae and F. moniliforme was found predominant on all tested hybrid rice varieties. Singh et al. (2018) from northeastern state of Mizoram also reported that among 21 fungi isolated from the farmers saved seed $F$. moniliforme was pre dominant in all tested rice samples ranging from $15-35 \%$ and $54-82.0 \%$ in agar plate and blotter paper method, respectively.

\section{Conclusion}

In the present study, all the samples subjected to blotter and agar plate method of detection were found to be associated with either one or more fungi and none of the sample was free from the fungal infection. In agar plate method, a greater number of mycoflora was detected than blotter method. Fungi Bipolaris, Fusarium and Curvularia lunata was found predominant in blotter method while Fusarium sp. and Curvularia was dominant in agar method. All the rice seed samples collected from different locations of northeast region showed varying percent of occurrence of seed borne fungi. Since, rice is the staple food crop of this region use of pathogen free seed and seed health test to detect and identify the associated mycoflora becomes vital in order to take up appropriate management strategies for successful rice cultivation.

\section{Acknowledgement}

The authors would like to thank all the provider of rice seed samples from different locations of West Bengal, Tripura, Meghalaya and Arunachal Pradesh. The authors are also grateful to Department of Plant Pathology, B.C.K.V, West Bengal for providing necessary support and facilities during the course of experiment.

\section{Ethical standards}

Not applicable with this article.

\section{Conflict of interest}

The authors declare that they have no conflict of interest.

\section{Author contributions}

SD and SM designed the concept of the article. YU, MD and TD perform the experiments, collect the samples. YU, TD, SM wrote the manuscript, SM communicates to the journal time to time.

\section{References}

1. Agrawal RL. 1999. Seed Technology. 2nd ed. Oxford and IBH Publishing Co., New Delhi, pp. 87-97.

2. Archana B and HS Prakash. 2013. Survey of seedborne fungi associated with rice seeds in India. International Journal of Research in Applied Microbiology 3(1): 25-29.

3. Burnett HL and BB Hunter. 1991. Illustrated Genera of Imperfect Fungi, 4th ed., Burgess Publishing Co., Minneapolis, p. 241.

4. Butt AR, SI Yaseen and A Javaid. 2011. Seed borne mycoflora of stored rice grains and its chemical control. The Journal of Animal \& Plant Sciences 21(2): 193-196.

5. Das S, A Chakraborty and S Mahapatra. 2016. Effect of fungicidal mixture on severity of brown spot and blast of rice vis -s- vis meteorological factors on diseases progression in field. In: 3rd International Conference on Sustainable Agriculture and Environment ( $3^{\text {rd }}$ ICSAE) September 26-28, 2016, Warsaw, Poland -475- ISBN: 978-605-9831-95-6.

6. Don, R. 2006. ISTA handbook on seedling evaluation. International Seed Testing Association.

7. Gopalakrishnan C and V Valluvaparidasan. 2009. Seed borne microflora associated with rice seeds in Tamil Nadu, India. Crop Research (Hisar) 37: 207-209.

8. Gopalakrishnan C, A Kamalakannan and V Valluvaparidasan. 2010. Survey of seed-borne fungi associated with rice seeds in tamil nadu, India. Libyan Agriculture Research Center Journal International, 1(5): 307-309.

9. Habib A, N Javed, ST Sahi and M Waheed. 2012. Detection of seed borne mycoflora of different coarse and fine rice varieties and their management through seed treatments, Pakistan Journal of Phytopathology 24: 133-136

10. Ibiam OFA, CI Umemchuruba and AE Arnize. 2006. Seed borne fungi associated with seed of rice (Oryza 
sativa L.) in storage and from the field in Ohaozara and Onicha local government areas of Ebonyi state. World Journal of Biotechnology 7: 1062-1072.

11. Ibiam OFA, CI Umemchuruba and AE Arnize. 2008. Seed borne fungi associated with seed of rice (Oryza sativa L. Faro 12, 15, and 29) in storage and the field in Afikpo North local government area of Ebonyi state. Scientia Africana, 7: 1-4.

12. Mannaa M and KD Kim. 2016. Microbe-mediated control of mycotoxigenic grain fungi in stored rice with focus on aflatoxin biodegradation and biosynthesis inhibition. Mycobiology, 44(2): 67-78.

13. Mathur SB and O Konsdal. 2003. Common laboratory seed health testing methods for detecting fungi. Bassersdorf, Switzerland, ISTA, 425pp.

14. Mew TW and P Gonzales. 2003. A Handbook of Rice Seedborne Fungi. Laguna, Philippines/Enfield, NH, USA: International Rice Research Institute Science Publishers, Inc. 83pp.

15. Mian IH and GA Fakir. 1989. Fungi, Moisture Content and Germinability of Rough Rice Grains during Storage. Seed Research 17: 169-173.

16. Naveenkumar R, A Muthukumar, G Sangeetha and R Mohanapriya. 2017. Developing eco-friendly biofungicide for the management of major seed borne diseases of rice and assessing their physical stability and storage life. Comptes Rendus Biologies, 340(4): 214-225.

17. Nguefack J, V Leth, JL Dongmo, J Torp, PA Zollo, and S Nyasse. 2008. Use of three essential oils as seed treatments against seed-borne fungi of rice (Oryza sativa L.). American-Eurasian. Journal of Agricultural and Environmental Science, 4(5): 554-560.
18. Oh JY, SN Jee, Y Nam, H Lee, MI Ryoo and KD Kim. 2007. Populations of fungi and bacteria associated with samples of stored rice in Korea. Mycobiology, 35(1): 36-38.

19. Ora N, NAN Faruq, MT Islam, N Akhtar and MM Rahman. 2011. Detection and identification of seed borne pathogens from some cultivated hybrid rice varieties in Bangladesh. Middle-EastJournal of Scientific Research 10: 482-488.

20. Roy AK. 1983. Rice grain discoloration in Assam, India. International Rice Research Newes 9: 10.

21. Sharma A and AS Kapoor. 2016. Detection of seed borne mycoflora associated with some rice varieties grown in Himachal Pradesh. The Bioscan, 11(4): 2733-2739.

22. Sharma HL, HS Randhawa, A Kapur and S Singh. 1987. Seed Discoloration in Rice. Seed Research and Production Unit 24(1): 37-41.

23. Sharma RC and HS Chahal. 1996. Multilocational evaluation of seed health of parental lines of hybrid rice. Plant Disease Research 11(2): 169- 172.

24. Singh AR, T Boopathi, SB Singh, SK Dutta, LS Singh, SL Saha and NH Singh. 2018. Seed Borne Mycoflora of Tribal farmers' Saved Hill Rice, Oryza sativa in Northeast of India. Indian Journal of Hill Farming, Special issue: 58-65.

25. Sunder S, DS Dodan and SC Ahuja. 1989. Chemical control of glume discolouration of rice. Indian Journal of Plant Pathology 7(1): 69-71.

26. Uma V and EG Wesely. 2013. Seed borne fungi of rice from South Tamil Nadu. Journal of Academia and Industrial Research 1: 612-614. 